\title{
PROTECTION OF HOUSING RIGHTS OF FOREIGNERS IN THE NOTARIAL AND CIVIL PROCESSES OF UKRAINE: PROCEDURAL ORDER
}

\section{Karmaza Oleksandra ${ }^{1}$ \\ Grinenko Olena ${ }^{2}$}

DOI: https://doi.org/10.30525/978-9934-571-78-7_36

Abstract. The purpose of this work is a comprehensive analysis of the protection of housing rights of foreigners in the notarial and civil proceedings in according to the legislation of Ukraine, and the formulation of science-based proposals to improve the theoretical and practical foundations for the definition of the rights of foreigners in Ukraine. The subject of the research is the legal regulation of the protection of the indubitable right to housing for foreigners in the notarial process and the legal regulation of the protection of housing rights of foreigners in respect of which there is a dispute. The object of research is the social relations that arise in the area of protection of the rights of foreigners in the notarial and civil processes of Ukraine. The work uses a wide range of methods of scientific knowledge, including philosophical, general scientific and special-legal, which collectively constitute the methodological base of research. For example, among the philosophical methods the basis is a dialectical method of research, which allowed to analyze the protection of housing rights of foreigners by a notary and a judge and study the subject as a dynamic category. It is proved that for foreigners in Ukraine a national legal regime is established, on the basis of which foreigners who are legally residing in Ukraine use the same rights and freedoms, and have the same duties as citizens of Ukraine - with the exception of, established by the Constitution and laws of Ukraine, and international treaties of Ukraine. The foreigners in Ukraine have the right to approach to a notary, a court or other institutions for the protection and restoration of their right to housing. In this case, social relations are international character, because they are

${ }^{1}$ D.Sc. (Law), Professor,

Institute of Continuing Education Taras Shevchenko National University of Kyiv, Ukraine

${ }^{2}$ D.Sc. (Law), Professor,

Legislation Institute of the Verkhovna Rada of Ukraine, Ukraine 
linked to national legal systems, and in practice there is a conflict of interest: the right of a country must be applied to settle these relations.

\section{Introduction}

According to Article 3 of the Constitution of Ukraine, the approval and guarantee of human rights and freedoms is the main responsibility of the state. The state creates conditions under which each citizen will be able to build house, purchase it or rent it (Article 47 of the Constitution of Ukraine). If the rights to housing of citizens are violated, unrecognized and disputed, their rights are protected by the court. (Article 55 of the Constitution of Ukraine) Thus, at the legislative level, citizens of Ukraine, as well as foreigners and stateless persons in Ukraine, are guaranteed and ensured protection of the right to housing.

Foreigners who legally stay in Ukraine are implementing their housing rights in the notarial and civil proceedings of Ukraine. For example, foreigners have the right to apply to the notary for the certification of agreement of sale and purchase apartment located in Ukraine, a rental agreement in Ukraine, the accept of inheritance, which includes housing, etc. In the case of disputes regarding housing that located on the territory of Ukraine, they may apply to the court for resolving the dispute in court. So, the protection of the right of foreigners to housing in Ukraine is of a dynamic nature and contingent upon the will of the foreigner, the existence of a rule of law, and other grounds established by the law of Ukraine, provided that the other is not provided for by an international treaty in force.

The relevance of the topic is determined by the significance of housing as a particularly valuable material good in every person's life, as well as the fact that the right to housing in Ukraine is provided by a special legal mechanism. In addition, in the modern period of development of the state and Ukrainian law there is a need to solve housing problems with the help of new conceptual approaches, in particular, by creating at the scientific level a holistic legal institute of a civilized legal process in which independent legal processes (notarial, civil and executive processes) are united by a common the legal goal is to ensure the protection of citizens' rights in Ukraine. This research is a continuous of work of A. Karmaza and D.Kousherets [1] and other studies by A.Karmaza of the protection right to housing in Ukraine [2; 3].

The purpose of this work is a comprehensive analysis of the protection of housing rights of foreigners in the notarial and civil proceedings 
in accordance with (according to) the legislation of Ukraine, and the formulation of science-based proposals to improve the theoretical and practical foundations for the definition of the rights of foreigners in Ukraine. The achievement of the goal involves solving the following scientific tasks: to conduct a study theoretical foundations for the protection of housing rights in the notarial and civil processes of Ukraine; to analyze the current situation of regulation of public relations to housing in a notarial and civil process with the participation of foreigners; to find out the reasons that lead to violations of the rights to housing of foreigners in Ukraine.

The methodological basis of the research is the general scientific, philosophical and special legal methods of scientific knowledge of social phenomena, in particular, those concerning the protection of the living rights of foreigners in Ukraine.

\section{Features of protection of housing rights of foreigners in the notarial process of Ukraine}

The presence of a foreign element in the notarial process of Ukraine, which implements the housing rights of foreigners, is a prerequisite for the selection and research of a notarial process with a foreign element in relation to housing. For example, citizen of Israel had been living in Ukraine, he had left a testament for his heirs - citizen of Israel and Ukraine apartment that located in Ukraine and Israel. In this case, the notarial actions related to the issuance of the certificate of the right to inheritance will be investigated in the theory of the notarial process as a notarial act with a foreign element, and in practice the notary will have a problem of choosing the application of national or foreign legislation regarding the possibility of conducting such an inheritance. Thus, the problem of inheritance of housing is an actual topic of research. In addition, the relevance of the topic is determined by the insignificant number of scientific works on the issue raised, since they generally examine the general aspects of the international notarial process [4], the implementation of notarial acts by officials of the consular institutions of Ukraine [5], etc.

Taking into account Art. 1 of the Law of Ukraine «On Private International Law» [6] concerning the forms of a foreign element, as well as researching the notarial practice of Ukraine, we note that the foreign element in the notarial process of Ukraine regarding the protection of housing rights is predominantly a foreign legal entity that is legally residing in Ukraine. 
In addition, the foreign element can be an object - a housing that located in the territory of a foreign country. For example, a citizen of Ukraine on the territory of Ukraine has the right to conclude a gift agreement, the right to which is registered in a foreign state, if it is provided for by international treaties of Ukraine and doesn't contradict the law of a foreign country. Also, a foreign element is a legal fact that affects the emergence, change and termination of legal relations with regard to housing. For example, in a marriage contract concluded by a notary public who is a citizen of Ukraine and France, the legal regime for the use of housing, which will be acquired in Bulgaria, may be determined. We draw the attention to the fact that a foreign element can be both subject and object. For example, after the death of a citizen in Ukraine, an inheritance has emerged, which included a flat, the right to which is registered in Ukraine, and a house whose law is registered in France, and foreigners are successors.

That is, the complication of the foreign element of the notarial process regarding housing provides such a legal process of an international character and requires the use of special methods for regulating the legal relationship with housing.

Having examined the norms of the Law of Ukraine «On Notary», we note that the commission of notarial acts concerning housing with a foreign element carries out state and private notaries, as well as in cases and within the limits established by law, local authorities, adhering to the principles of the notarial process. The procedure for the commission of such notarial acts in Ukraine is established by the Laws of Ukraine «On Private International Law», «On Notary», international treaties of Ukraine, as well as other legislative acts, for example, the Procedure for carry out notarial acts by notaries of Ukraine, etc.

The analysis of the norms of the Law of Ukraine «On Notary» gives grounds for concluding that the notarial acts with a foreign element in respect of housing, the right of which is registered in Ukraine and which are committed by notaries and include: certification of transactions (property sale and purchase, renting of house, life maintenance (care), testament, etc.); taking measures for the protection of inherited property, that includes housing; certification of the right to inheritance, certificate of title to the share in the joint property of the married couple in the event of the death of one of the married couple; imposition and removal of a ban on the alienation of housing (the right to housing); implementation of other notarial acts determined by law. 


\section{Karmaza Oleksandra, Grinenko Olena}

Going on the scientific researches by S. Fursa and other Ukrainian scholars [7, p.380] concerning the theoretical model of the Ukrainian notarial process, as well as improving the scientific results of $\mathrm{O}$. Karmaza, V. Strelko and O. Grinenko [8] in the part of the theoretical model of the notarial process with the foreign element (international notarial process), we can note that the model of the notarial process of Ukraine from the theoretical point of view consists of notarial proceedings concerning the housing (proceedings concerning the certification of the contract, the conduct of the inheritance, etc.), to each of which is divided into stages, which committed procedural actions of the proceedings.

To pay attention, the model of the notarial process with a foreign element or the model of the notarial process is the result of research that takes place at the scientific and practical levels, but the law of Ukraine does not establish or use such terms «notarial process», «notarial proceedings» and «stages of notarial proceedings «. In our opinion, the use of such terms in the law of Ukraine is possible provided the adoption of the Notarial Code of Ukraine.

Speaking about notarial proceedings with a foreign element in respect of housing, the right to which is registered in Ukraine, should be understood in the narrow sense of the implementation on behalf of the state of Ukraine within the limits of authority, in the manner provided for by the law of Ukraine, unless otherwise provided by an international agreement of Ukraine, procedural actions by notaries, aimed at protecting the rights and interests of subjects of legal relations with a foreign element in relation to housing in the field of indisputable jurisdiction. Broadly speaking, it is a comprehensive institute of public-law orientation, regulated by Ukrainian legislation and generally accepted principles and norms of international law, which are necessary to provide qualified legal assistance to foreigners in order to ensure their housing rights in Ukraine.

Depending on the legal nature of the notarial proceedings with the foreign element regarding housing, there are the following stages of proceedings: opening of notarial proceedings, preparation for commissioning of notarial proceedings, commission of notarial acts and the issuance of a notarial deed. In addition, in the event that after the notarial proceedings with a foreign element in respect to housing have been imposed on notaries, the duty to perform state registration of property rights and other property rights to housing in the notarial process is a separate stage of administrative proceedings electronic registration of rights to housing and their encumbrances. 
Thus, the first stage of the notarial proceedings is the fixation of the application of the foreigner to the notary with a request to make notarial acts regarding the housing, for example, to certify a contract of sale of housing, the right to which is registered in Ukraine. The second stage is the provision of a notarial act with a foreign element. At this stage, the notary clarifies the law of which country is used in the exercise of a notarial act and decides on the possibility of a notarial act or refusal to do it.

The feature of this stage of the proceedings is the assessment of the legal situation and the implementation of legal qualifications in accordance with the requirements of the Law of Ukraine «On International Private Law». The assessment of the legal situation consists in the fact that in the event of foreigner's application to a notary, the latter should analyze the relations of housing in terms of the presence of a foreign element in them or the emergence of such an element in the future. Such an assessment is based on a thorough, complete, objective and direct study of available materials in the case. To assess the legal situation, the notary uses data provided by the parties regarding their legal status, place of residence, place of residence and its legal regime, and the goals and consequences that the interested parties want to achieve.

The assessment of the subject of treatment as a foreigner is carried out in accordance with the general rules defined by the law of Ukraine. The notary establishes the identity of a foreigner and checks his civil legal capacity and civil capacity in accordance with the requirements of the Law of Ukraine «On Private International Law» and the Law of Ukraine «On Notary», as well as international treaties of Ukraine.

In conclusion, the first the notary must make sure that the individual isn't a citizen of Ukraine before performing the notarial acts. The duty to prove this fact on a foreigner who appealed to the notary for a notarial act. For confirmation of this circumstance is may be official documents issued by the competent authorities of a foreign state, followed by the nationality of a person, may be provided. As a rule, such a document is a national passport of a foreigner or a document that replaces it, for example, a certificate of nationality, etc.

Having established the identity of the foreigner, as well as the fact of his personal appeal for the commission of notarial acts under his own name, the notary establishes his civil legal capacity and civil capacity. As a rule, at this stage there is a need to apply the relevant material rules of foreign law. 
According to Art. 17 of the Law of Ukraine «On International Private Law» the emergence and termination of a civilian legal capacity of an individual is recognized by his Proper law (lex personalis), the law of nationality (lex patriae, lex nationalis) or the law of domicile (lex domicilii). Foreigners have civil legal capacity in Ukraine on a par with citizens of Ukraine, except in cases stipulated by law or international treaties of Ukraine (Article 17 of the Law).

However, the definition of civil legal capacity in existing international treaties of Ukraine may differ from the Law of Ukraine «On Private International Law». Art. 22 of the Treaty between Ukraine and the Czech Republic on legal assistance in civil matters stipulates that the legal capacity of an individual is determined by the legislation of the Contracting Party of which that person is a citizen. The law of nationality determines the legal capacity of citizens and in the Treaty between Ukraine and Romania (Article 22), the Treaty between Ukraine and Korea (Article 21), the Treaty between Ukraine and Moldova (Article 21), the Treaty between Ukraine and Georgia (Article 22) The international treaty of Ukraine establishes the attachment only to the law of citizenship of the state (lex patriae).

Civil capacity of a foreigner in accordance to Art. 18 of the Law of Ukraine «On International Private Law» is defined by his personal law the law of the country of which he is a citizen or the law of the country in which he has his residence or is engaged in the main activity. However, the civil capacity of foreigners to commit in Ukraine the rights and obligations arising from the damage that determined by the law of the country where the transaction was made (lex loci contractus) or the occurrence of obligations in connection with the damage (lex loci delicti commissi), the law of Ukraine, unless otherwise provided by law or an international treaty of Ukraine. The grounds and legal consequences of declaring a citizen incapacitated or limiting his civil capacity are governed by a person's personal law (lex personalis).

Proper law The legislation of Ukraine subordinate the civil law and civil capacity of a proper law - lex personalis. The application of a proper law of foreigners to a civilian capacity means that a foreigner who is capable of a personal law - the law of nationality, for example, should be considered capable in Ukraine. However, in practice, there may be a situation where the referral to lex patriae may prove problematic as a person may have multiple citizenship. In this case, the Law of Ukraine «On Private International Law» provides for the application of the collision principle of 
the closest connection, in particular, the place of residence or occupation of a foreigner's main activity (Article 16 of this Law).

The feature of notarial acts with a foreign element in relation to housing, is a notary checking the legality of a foreigner's stay in Ukraine. In confirmation of this notary will record the details of the visa, and the duration of its.

Having established the presence of a foreign element in the notarial proceedings concerning housing, and also having found out that in Ukraine for foreigners the national legal regime is operating, the notary moves to the next step - the choice of the state's right to settle housing rights. In the doctrine, this stage is called «the establishment of the legal basis of the case» [9, p. 260]. He appeals to the conflict of the Law of Ukraine «On Private International Law» and the current international treaties of Ukraine. According to Art. 4 of the Law of Ukraine «On Private International Law» the right to be applied to private law relations with a foreign element is determined in accordance to the conflict rules and other provisions of the conflict law of this Law, other laws, and the current international treaties of Ukraine.

For example, if a foreigner inheriting an apartment in Ukraine inherited and legally registered in Ukraine, the relations in accordance to the Law of Ukraine «On Private International Law» are regulated by the law of Ukraine. When an agreement of sale and purchase of housing is registered, the right to which is registered in Ukraine, the form of the transaction is determined by the law of Ukraine (Article 31 of this Law), the contract is entered into in writing and is subject to a notarial certificate, and the right to housing - state registration. such contract has been made since its state registration (Article 210 of the Civil Code of Ukraine).

In practice, a situation may arise when a citizen of Ukraine applies to the notary in Ukraine for a certificate of a donation contract, the right of which is registered in a foreign state. Such an appeal may be due, for example, to a disease. In this case, the notary will carry out a comprehensive analysis of the norms of the Laws of Ukraine «On International Private Law» and «On Notary», as well as the current international treaties of Ukraine, will be governed by the requirements of foreign law. In case the law of a foreign state allows him to perform such notarial acts - a notary in Ukraine will do them. In this case, the application of the norms of foreign law in the notarial process, with a direct indication of this in the conflict of laws, is a duty, and not a notary's right. 


\section{Karmaza Oleksandra, Grinenko Olena}

The problem of legal qualification is extremely difficult for theory and practice. In particular, V. Kisil points out its complexity in private international law. He notes that essentially three fundamental questions are solved: the search and establishment of an appropriate issue of conflict to be applied, the qualification of a collision binding, and the problem of qualification and interpretation of norms and concepts of foreign law are solved [10, p. 45-46]. Thus, if the legislation of Ukraine on private international law provides for the application of the substantive law of a foreign state, the notary will have a problem in establishing the content of the rules of foreign law, as well as in clarifying the mechanisms for the application of such rules of the law of a foreign state and sources of obtaining the relevant information.

According to Art. 8 of the Law of Ukraine «On Private International Law», when applying the law of a foreign state, the notary establishes the content of its norms according to their official interpretation, practice of application and doctrine in the corresponding foreign state. Therefore, in order to establish the content of the rules of the law of a foreign state, the notary has the right to apply to the Ministry of Justice of Ukraine, other competent authorities and institutions in Ukraine or abroad or to involve experts. In addition, according to Art. 8 of this Law, persons who participate in the notarial procedure for housing, have the right to submit documents that establish the content of the rules of the law of the foreign state to which they refer.

The national law of Ukraine provides for formal and informal establishment of norms of foreign legislation. Thus, within the formal establishment of the norms of foreign law of the notary, to pay attention to the existence of existing international treaties of Ukraine, for example, the European Convention on Information on Foreign Legislation (1968). As for the involvement of experts in establishing the content of the rules of foreign law, the Law of Ukraine "On Private International Law» or the Law of Ukraine «On Notary» doesn't specify who can be an expert on legal issues in establishing the content of the rules of foreign law (a scientist certified expert), as well as doesn't establish the procedure for the implementation of such experts, etc. Therefore, in our opinion, this problem should be solved when the Law of Ukraine «On International Private Law» will be change.

According to the analysis of Art. 8 of the Law of Ukraine «On Private International Law», in parallel with the official procedure for establishing 
the content of norms of foreign law, or separately from it, there may be an informal way. The notary can take advantage of the help of those who take part in notarial proceedings with a foreign element in respect to housing. However, taking into account the legality of obtaining such documents, we consider the notary to be careful when referring to them at the time of the relevant notarial acts.

Neither the law nor the doctrine can determines the legal effect for notarial proceeding with a foreign element in the event of an appeal with a notarial power of attorney to provide legal assistance to the competent authority of a foreign state. In our opinion, in this case, the notary must stop the notarial proceeding by making a decision to suspend the proceedings within a reasonable time, which is determined in accordance to the nature and complexity of the notary's case, as well as its legal effect.

At the stage of application of the norms of foreign law, a notary may establish the existence of gaps in the content of foreign law. In this case, in our opinion, the notary, using Part 4 of Art. 8 of the Law of Ukraine «On Private International Law», applies the law of Ukraine. In addition, when applying the rules of the law of a foreign state, first of all, he must proceed from their official interpretation, and then from the practice and doctrine of their application in a foreign country. Also, the notary should keep in mind that in some cases the application of the rules of foreign law may in fact and legally be impossible, for example, when it comes to referring to the right of an unrecognized foreign state. In this case, modern Ukrainian practice stay in the position of mandatory recognition of the state for the application of its right.

It should be noted that the application of the norms of foreign law in the notarial process is one of the most difficult stages of a notarial proceeding with a foreign element. It is proposed in the Procedure for the performance of notarial acts by notaries of Ukraine to provide a separate section on the application of the norms of foreign law in the notarial proceeding, taking into account the peculiarities defined by the Law of Ukraine «On International Private Law».

Also, the feature of notarial proceedings with a foreign element in relation to housing in accordance to Art. 100 of the Law of Ukraine «On Notary» is the provision of notarized legal documents drawn up abroad with the participation of foreign authorities. Documents without legalization are accepted by notaries in cases stipulated by the law of Ukraine, current 
international treaties of Ukraine. For example, the Convention abolishes the requirement of legalization of foreign official documents (1961).

Having checked at the stage of preparation for the commission of notarial acts with the foreign element in respect to housing, all the conditions, the notary takes a decision to move to the next stage of proceedings - the direct commission of notarial acts with a foreign element in relation to housing or motivated refusals to commit notarial acts. Also, it should be noted that at the third stage of the notarial proceedings in accordance with Art. 48 of the Law of Ukraine "On Notary», for example, when certifying transactions on the relevant documents are issued certifying inscriptions. We emphasize that such a notarial procedure is subject to the law of law enforcement, the law of Ukraine, which is reflected in the notarial process of the action of the collision principle of the law of the court, - it is unchanged, as in the case when the parties to the transaction are citizens of Ukraine, and in the case when the party or the parties are foreigners. Having analyzed the notarial practice, it should be noted that mainly notarial proceedings with a foreign element in respect of housing concern hereditary (the issuance of a certificate of inheritance consisting of housing), family (marriage contract), as well as property and liability relationships (certificate of purchase sale of housing, contract for the establishment of servitude, etc.).

With regard to the language of the contract, then, by virtue of imperative requirements of the Ukrainian legislation, the text of the contract must be set out in the state language - in Ukrainian. If the foreign person doesn't speak the state language, the text of the document will be translated by a notary public or a translator in the language in which he / she speaks (Article 15 of the Law of Ukraine «On Notary»). In our opinion, the texts of transactions with a foreign element in respect of housing, which are certified by a notary, should be taught in two languages - state and foreign.

When performing notarial proceedings with a foreign element in respect of housing, in parallel with the law of Ukraine, the notary may, apply foreign law, unless otherwise provided by law or an international treaty of Ukraine. For example, foreigners may apply for a notary in order to certify an apartment exchange agreement, the right of which is registered in Ukraine and Kazakhstan. Thus, the subject of the contract are apartments that registered in different states. In accordance with the general rule established by Art. 43 of the Law of Ukraine «On International Private Law», the choice of law is carried out with the consent of the parties on the basis 
of the autonomy of their will. In this case, according to Art. 5 of the Law of Ukraine «On Private International Law», the parties may choose the right as a whole for the contract, and for certain parts of the contract, in particular, for the transfer of housing on the territory of Ukraine - the material law of Ukraine, and to the transfer obligations housing in Kazakhstan - material law of Kazakhstan. It should be noted that in the absence of the consent of the parties, the law applicable to the contract of exchange of housing may be the substantive law of Ukraine as the right of the place of conclusion of the contract.

To tell about notarial proceeding with a foreign element in respect of housing, the right to which is registered in Ukraine, should be understood as a notary within the limits of authority, in the manner prescribed by the legislation of Ukraine, unless otherwise provided by an international treaty of Ukraine, procedural legal actions, aimed at protecting the indisputable rights of foreigners involved in the acquisition of title to or use of housing, the right of which is registered in Ukraine. The peculiarities of such proceedings are: establishing the presence of a foreign element; realization of legal qualification; application of conflict of legal rules; subordination of the enforcement of the law - the law of Ukraine, and in cases established by law or international treaty of Ukraine - foreign law, etc.

\section{Features of protection of housing rights of foreigners in the civil process of Ukraine}

According to Art. 55 of the Constitution of the rights and freedoms of individuals and citizens are protected by the court. In addition, Art. 73 of the Law of Ukraine «On Private International Law» stipulates that foreigners, foreign legal persons, foreign states (their public authorities and officials) and international organizations have the right to apply to the courts of Ukraine for the protection of their rights, freedoms or interest. In the case of non-recognition, challenge or violation of residential rights, foreigners have the right to apply to a court in Ukraine for the protection of their rights.

The consideration of civil cases with a foreign element in respect of housing in the Ukrainian court has the features set by the Law of Ukraine «On Private International Law», the Civil Procedural Code of Ukraine, the current international treaties of Ukraine, in particular, on the determination of the legal status of a foreigner, jurisdiction, the service of court sentences abroad etc. After analyzing the scientific Ukrainian literature [12, p. 217-222], 
$[13$, p. $167-177 ; 14]$ we can make a conclusion that it examines the general grounds for civil cases with a foreign element, but there are almost no studies on civil cases dealing with a foreign element in terms of housing [15]. Therefore, in the absence of such studies, as well as the existence of different jurisprudence, the norms of the Civil Procedural Code of Ukraine in the new edition, the topic of the study is relevant and timely.

The analysis of the jurisprudence in Ukraine has shown [16] that foreigners in civil matters in Ukraine are mainly plaintiffs, rarely respondents or concerned persons. The most widespread cases are cases of lawsuits against foreigners living in Ukraine.

The sources of regulation of the participation of foreigners in civil housing cases are the norms of international law, as well as the general and special norms of national law of Ukraine. Such sources are national legislation and international treaties, in which Ukraine is involved [17]. The legislation of Ukraine includes the Constitution, the Civil Procedural Code of Ukraine (hereinafter - the CPC), the Law of Ukraine «On Private International Law», etc., is considered as the main source of regulation of relations in a civil case involving housing with the participation of a foreigner. However, a complex regulation of civil procedural relations with a foreign element is carried out only at the same time as the combination of national and international law, which includes existing international treaties of Ukraine. For example, the Convention on the Service Abroad of Judicial and Non-Judicial Documents in Civil and Commercial Matters (The Hague, 1965), the Convention on Receiving Evidence in Civil and Commercial Matters Abroad (The Hague, 1970), the Convention on Legal Aid and Legal relations in civil, family and criminal cases (Minsk, 1993), etc. Moreover, Ukraine has made international treaties on legal aid and legal relations in civil matters with nearly 30 countries of the world. We agree with the conclusion of the High Specialized Court of Ukraine for the consideration of civil and criminal cases that the court can not apply the law regulating the legal relationship being treated, except as an international treaty. At the same time, existing international treaties are applied if they don't contradict the Constitution (paragraph 4 of the resolution of the Plenum of the Supreme Court of Ukraine of November 1, 1996, № 9 «On the application of the Constitution of Ukraine in the administration of justice»).

The feature of considering civil cases with a foreign element in housing is the sources of regulation of the participation of foreigners are dual in nature: 
on the one hand, they include the norms of domestic legislation of Ukraine, and, on the other hand, the existing international treaties of Ukraine.

The feature of considering civil cases with a foreign element in relation to housing also include the definition of jurisdiction, as in accordance to Art. 76 of the Law of Ukraine «On Private International Law», courts can accept their proceedings and consider any cases with a foreign element, in particular, in the case where the respondent in the territory of Ukraine has a place of residence or location, or there is a home to which you can impose penalties, etc. In addition, as is known from the jurisprudence, a significant number of civil matters with a foreign element in respect of housing are cases of disputes concerning spouses' residential relations, inheritance disputes relating to housing.

The analysis of the norms of Ukrainian legislation has shown that the establishment of a civil case with a foreign element in respect to housing takes place in several stages. The first stage, the judge determines international jurisdiction, as Y. Chernyak rightly states, determines which court is competent to administer justice in this case [18, p. 298], and then territorial jurisdiction. Definition of jurisdiction is carried out in accordance to the norms of domestic legislation of Ukraine, in particular, the Criminal Procedure Code, the Law of Ukraine «On International Private Law» and current international treaties of Ukraine, and also depends on the category of the dispute.

According to Art. 77 of the Law of Ukraine «On Private International Law» the exclusive jurisdiction of the courts of Ukraine includes the consideration of civil cases with a foreign element in respect of housing in cases where the housing in respect of which the dispute exist, is located on the territory of Ukraine, or when the dispute concerns the validity of records about the real right to housing, etc. In other words, when considering disputes concerning housing in Ukraine, the law of which is registered in Ukraine, there is an issue of conflict «court law» (lex fori). In addition, international treaties of Ukraine provide that in the case where the subject of the dispute is housing, the right to which is registered in Ukraine, exclusively within the competence of the court of Ukraine assigned the resolution of such disputes. An action on the recognition of the right to own a home, the protection of the right to own a home, the removal of obstacles to the implementation of easement, the recognition of the validity of the entry in the State Register of real rights to real estate, etc., is considered in the courts of Ukraine. 


\section{Karmaza Oleksandra, Grinenko Olena}

In addition, the principle of the law of the court operates also in determining the procedural and legal status of foreigners. According to Art. 74 of the Law of Ukraine «On Private International Law» the procedural legal capacity and capacity of foreign persons in Ukraine are determined in accordance with the law of Ukraine. Note that this article of the Law refers specifically to the procedural legal capacity and capacity of citizens, which is established in Art. 46 and 47 CPC.

The law of Ukraine provides for who can be a party to the housing case, who has the right to apply for protection of the violated, unrecognized or disputed housing law, as well as the ability to perform procedural actions, to participate in the civil process, etc.

In addition, according to Art. $58 \mathrm{CPCs}$ of foreigners can take part in a civil housing case personally or through their representative. Personal involvement in the case doesn't deprive them of having a representative in this case. The documents that certifying the credentials of the representative must meet the requirements of Art. $62 \mathrm{CPCs}$, as well as be legalized. Two types of legalization of official documents are used in Ukraine: consular legalization, which takes place in accordance with the procedure established by the Convention on Consular Relations (Vienna, 1963), and the apostille in accordance with the Convention, which abolishes the requirement of legalization of foreign official documents (The Hague, 1961). etc. the apostille in accordance with the Convention, which abolishes the requirement of legalization of foreign official documents (The Hague, 1961). etc.

According to Art. 9 CPC civil proceedings are carried out on the state language - in Ukrainian. In case when foreigners who participate in civil matters with a foreign element in respect of housing do not speak Ukrainian they have the right to participate in the process with translator. The feature of considering civil cases with a foreign element in relation to housing is to provide foreigners with the right to speak in their native (foreign) language.

Consideration of civil cases with a foreign element in respect of housing, as noted above, is carried out with the use of the issue of conflict (lex fori), on the basis of the norms of law of Ukraine, the Constitution, the Criminal Code, and the Law of Ukraine «On Private International Law». Instead, in the event that the law of Ukraine or the international treaty of Ukraine establishes the application of the norms of foreign law, the court applies the rules of law of other states, defining their validity in time and space. It is important to note that the court may apply not only foreign laws, but 
also customs and judicial practice, to the extent that they are recognized as sources of law in the states, as the Law of Ukraine «On Private International Law» provides.

The other feature of consideration of civil cases with a foreign element in relation to housing is the application of the rules of foreign law, judicial practice and customs in cases established by an international treaty of Ukraine.

As a general rule, the jurisdiction of the court of Ukraine is limited to its territory. However, when considering a civil case with a foreign element in relation to housing, a court may need to present a summons to challenge a court, conducting an examination, as well as other procedural actions abroad, etc.

After analyzing Ukrainian law, we can make the conclusion that the general rules of appeal of the courts of Ukraine to foreign courts with a power of attorney to perform certain procedural actions in civil matters with a foreign element in respect of housing are established by the domestic legislation of Ukraine, Art. 80 of the Law of Ukraine «On International Private Law» and Art. 498 CPC, as well as international treaties of Ukraine. For example, the Convention on the Service Abroad of Judicial and Extrajudicial Documents in Civil or Commercial Matters (The Hague, 1965), the Convention on Civil Procedure (The Hague, 1954), the Convention on Receiving Evidence in Civil or Commercial Matters Abroad (The Hague, 1970), as well as with existing bilateral international treaties of Ukraine, for example, Section II of the Treaty between Ukraine and the Republic of Hungary on legal assistance in civil matters.

As is known, the consideration of civil cases with a foreign element in respect of housing and the making decision in a case shall be conducted in compliance with the legislation of Ukraine, unless otherwise provided by an international treaty of Ukraine. According to Art. 259 of the Civil Procedure Chamber proceedings in court, as a general rule, ends with the adoption of a court decision - an act of justice, which is carried out on behalf of the state of Ukraine, and protects the violated, disputed, unrecognized residential rights and interests of foreigners in Ukraine. To pay attention to the fact that the decision of the court of Ukraine operates in the territory of Ukraine, as well as in the territory of a foreign state, in case of recognition by the state of its action in its territory. As a rule, recognition and implementation of judgments of a court of Ukraine abroad is possible in the case of an international treaty 


\section{Karmaza Oleksandra, Grinenko Olena}

of Ukraine, the provisions of which provide for the obligation of mutual recognition and implementation of foreign court decisions.

In conclusion, foreigners who legally stay in Ukraine, in order to protect their housing rights, have the right to appeal to the court of Ukraine. Applying the principle of the national legal regime established for such persons in Ukraine, and hold to the requirements of Ukrainian law, Ukrainian courts can take proceedings and consider civil cases with a foreign element regarding housing. Civil cases in respect to housing have a transboundary nature, as they are complicated by a foreign element, and the legal relationship goes beyond Ukraine, but the procedural order of their consideration is subject to the principle of lex fori, the law of Ukraine. In addition, in cases established by law or an international treaty of Ukraine, an exception to this principle and application of the rules of foreign law is possible.

\section{Conclusions}

Protection of housing rights of foreigners in the civil process, notarial process is based on the principle of a national legal regime, which is defined by the Constitution of Ukraine. It is proved that the features of notarial proceedings with a foreign element in relation to housing includes: establishing the form of a foreign element; realization of legal qualification; the application of conflict and material rules of law; subordination of the implementation of the law (lex notary) - the law of Ukraine, and in cases established by law or international treaty of Ukraine - foreign law, etc. It is known, that the signs of the civil process aimed at protecting the violated, unrecognized or challenged residential rights of foreigners are: the complexity of the civil process by a foreign element, the public-law nature of such a process, the application of the collisional method of regulation of relations, the implementation of justice on the basis of the principle of lex fori, if different doesn't stipulate by the current international treaty of Ukraine, regulation of relations between internal law of Ukraine and international law, implementation of procedural actions within the framework of the international legal mechanism legal aid and so on.

In order to create an effective legal framework in the area of protection of housing rights of foreigners, its focus on achieving common European standards for the observance of human civil rights and freedoms is proposed to change the legislative acts of Ukraine in terms of improving the procedure for the protection of residential rights in the international notarial process, the international civil procedure. 


\section{References:}

1. Karmaza O.O., Koucherets D.B. (2018). The ensuring the right to housing according to the legislation of Ukraine. Theoretical and practical mechanisms of development of legal science at the beginning of the third millennium: Collective monograph. Tbilisi: Izdevnieciba "Baltija Publishing", p. 197-214.

2. Karmaza O.O. (2013). Koncepciji okhorony ta zakhystu zhytlovykh prav v Ukrajini: materialjnyj ta procesualjnyj aspekty: monoghrafija [Conceptions of housing rights protection in Ukraine. Material and procedural aspects. Monograph]. Myronivka. 400 p. (in Ukrainian)

3. Karmaza O.O. (2018). The correlation of "The right to housing" and "Housing rights" definitions to the legislation of Ukraine. The International Scientific Periodical Journal «Modern Technology and Innovative Technologies», issue № 5, vol. 2, pp. 8-11. Retrieved from: https://www.moderntechno.de/index.php/meait/ issue/view/meait05-02/meait05-02

4. Kryshtopa O.M. (2012). Mizhnarodno-pravove reghuljuvannja notarialjnoji dijaljnosti [International legal regulation of notarial activity] ( $\mathrm{PhD}$ Law). Kyiv. 20 p. (in Ukrainian)

5. Ghrinenko O.O. (2005). Pravovyj status konsula pry vykonanni notarialjnoji funkciji: naukovo-praktychnyj posibnyk [Legal status of the consul in the performance of the notarial function: Scientific and practical guide]. Kyiv. 352 p. (in Ukrainian)

6. Verkhovna Rada Ukrajiny: Oficijnyj veb-portal: Zakonodavstvo Ukrajiny [Verkhovna Rada of Ukraine: Official Web-portal: Legislation of Ukraine]. Retrieved from: http://zakon2.rada.gov.ua/rada

7. Fursa S.Ja. (ed) (2012). Teorija notarialjnogho procesu: Naukovo-praktychnyj posibnyk [Theory of the notarial process: Scientific and practical manual]. Kyjiv. 920 p. (in Ukrainian)

8. Karmaza O.O., Ghrinenko O.O., Striljko V.Ju. (2018). Notarialjnyj proces $\mathrm{z}$ inozemnym elementom. Monoghrafija [Notarial process with foreign element. Monograph]. Kyjiv. 216 p. (in Ukrainian)

9. Dovghert A.S., Kysilj V.I. (ed) (2012). Mizhnarodne pryvatne pravo. Zaghaljna chastyna: pidruchnyk [International private law. General part: tutorial]. Kyjiv. 376 p. (in Ukrainian)

10. Dovghert A.S. (ed) (2008). Mizhnarodne pryvatne pravo. Naukovopraktychnyj komentar Zakonu [International private law. Scientific and Practical Commentary of the Law]. Kyjiv. 352 p. (in Ukrainian)

12. Bychkova S.S. (2011). Osoblyvosti cyviljnoji procesualjnoji pravosub'jektnosti inozemnykh osib v Ukrajini [Features of civil procedural legal personality of foreign persons in Ukraine]. Pravo Ukrajiny, no 2, pp. 217-222.

13. Bighun V.A. (1998). Pidsudnistj cyviljnykh sprav za uchastju inozemnogho elementu [Jurisdiction of civil cases involving a foreign element]. Visnyk Akademiji pravovykh nauk Ukrajiny, no 4(15), pp. 167-177.

14. Fursa S.Ja. (ed) (2010). Mizhnarodnyj cyviljnyj proces Ukrajiny: Navchaljnyj posibnyk [International Civil Procedure Process of Ukraine: Textbook]. Kyjiv. 328 p. (in Ukrainian). 


\section{Karmaza Oleksandra, Grinenko Olena}

15. Karmaza O.O. (2014). Koncepciji okhorony ta zakhystu zhytlovykh prav u cyvilistychnomu procesi: Dys. ... d-ra juryd.nauk [Concepts of protection and protection of housing rights in the civilization process] (D.Sc. Law). Kyiv. 477 p. (in Ukrainian).

16. Jedynyj derzhavnyj rejestr sudovykh rishenj Ukrajiny [The only state register of judicial decisions of Ukraine]. Retrieved from: http://reyestr.court.gov.ua/

17. Verkhovna Rada Ukrajiny: Oficijnyj veb-portal: Zakonodavstvo Ukrajiny [Verkhovna Rada of Ukraine: Official Web-portal: Legislation of Ukraine]. Retrieved from: http://zakon2.rada.gov.ua/rada

18. Dovghert A.S. (ed) (2008). Mizhnarodne pryvatne pravo. Naukovopraktychnyj komentar Zakonu [International private law. Scientific and Practical Commentary of the Law]. Kyiv. 352 p. (in Ukrainian) 